\title{
ACTIVE GEOTHERMAL SYSTEMS IN THE CONTINENTAL RIFT ZONES OF THE MENDERES MASSIF, WESTERN ANATOLIA, TURKEY
}

\author{
Özgür N. and Arife Çalışkan T. \\ Süleyman Demirel University, Faculty of Engineering, Department of Geological Engineering, \\ 32264 Isparta, Turkey, nevzatozgur@sdu.edu.tr
}

\begin{abstract}
The active geothermal waters of Kizlldere, Baylndir, and Salihli in the continental rift zones of the Büyük Menderes, Küçük Menderes and Gediz represent typical examples in the study area. The meteoric waters in the drainage areas of the rift zones percolate at NE-SW and/or NW-SE trending fault zones and permeable clastic sediments into the reaction zone of the roof area of a magma chamber situated in a probable depth of up to $5 \mathrm{~km}$ where meteoric fluids are heated by the cooling magmatic melt and ascend to the surface due to their lower density caused by convection cells. The volatile components of $\mathrm{CO}_{2}, \mathrm{SO}_{2}, \mathrm{HCl}, \mathrm{H}_{2} \mathrm{~S}, \mathrm{HB}, \mathrm{HF}$, and He out of the magma reach the geothermal water reservoir where an equilibrium between altered rocks, gas components, and fluids performs. Thus, the geothermal waters ascend in the tectonical zones of weakness at the continental rift zones of the Menderes Massif in terms of hot springs, gases, and steams. These fluids are characterized by high to medium $\mathrm{CO}_{2}, \mathrm{H}_{2} \mathrm{~S}$ and $\mathrm{NaCl}$ contents.
\end{abstract}

Keywords: Turkey, Menderes Massif, continental rift zones, active geothermal waters, geothermal modeling.

\section{Introduction}

The tectonic position of the eastern Mediterranean area between the Eurasian and African plates is controlled by the Anatolian and Aegean micro plates. The plate tectonic development results in the uplift of the Menderes Massif showing a dome shaped structure due to compressional tectonic features from Oligocene to Middle Miocene (Figure 1; Okay, 2001). From Early to Middle Miocene, the continental rift zones of the Büyük Menderes, the Küçük Menderes and the Gediz were formed by extensional tectonic features (Figure 2; Bozkurt, 2001), which strike E-W generally and are represented by a great number of geothermal waters, epithermal mineralizations, and volcanic rocks of Middle Miocene to recent age. The present-day geothermal waters, epithermal $\mathrm{Hg}, \mathrm{Sb}$ and $\mathrm{Au}$ mineralizations and young volcanoes are related to faults which strike preferentially NW-SE and NE-SW and locate diagonal to general strike of the rift zones. These faults are probably generated by compressional tectonic stress which leads to the deformation of uplift between two extensional rift zones (Özgür, 1998; Özgür et al., 1998a).

In addition to earthquake activities and heat flow anomalies in the continental rift zones of the Menderes Massif, the important localities of calc-alkaline towards basic towards acidic volcanic rocks were mapped which are distinguished by an $\mathrm{Rb} / \mathrm{Sr}$ age of 15,0 \pm 0,2 Ma in Karaburç, an K/Ar age of 16,7 \pm 0,5 Ma in Yenișehir (Özgür et al.,1997; Özgür, 1998) and an 7,5 Ma age of 20.000a in Kula (Ercan et al., 1992) and can be classified into Middle Miocene. These volcanic rocks are 
considered as products of continental crust due to isotope analyses of ${ }^{87} \mathrm{Sr} /{ }^{86} \mathrm{Sr}$ and ${ }^{143} \mathrm{Nd} /{ }^{144} \mathrm{Nd}$ and come into consideration as heat source for the geothermal waters in the rift zones of the Menderes Massif (Özgür, 1998). Therefore, we have selected three geothermal fields of Kizıldere, Bayındır and Salihli which are located in the rift zones of the Büyük Menderes, the Küçük Menderes and the Gediz and were investigated circumstantially (Figure 1). The aim of this paper is to present the hydrogeological, hydrogeochemical and isotope geochemical features of the geothermal waters in the rift zones of the Menderes Massif in combination with the origin and evolution of these waters and to make a hydrogeological modeling of the geothermal waters.

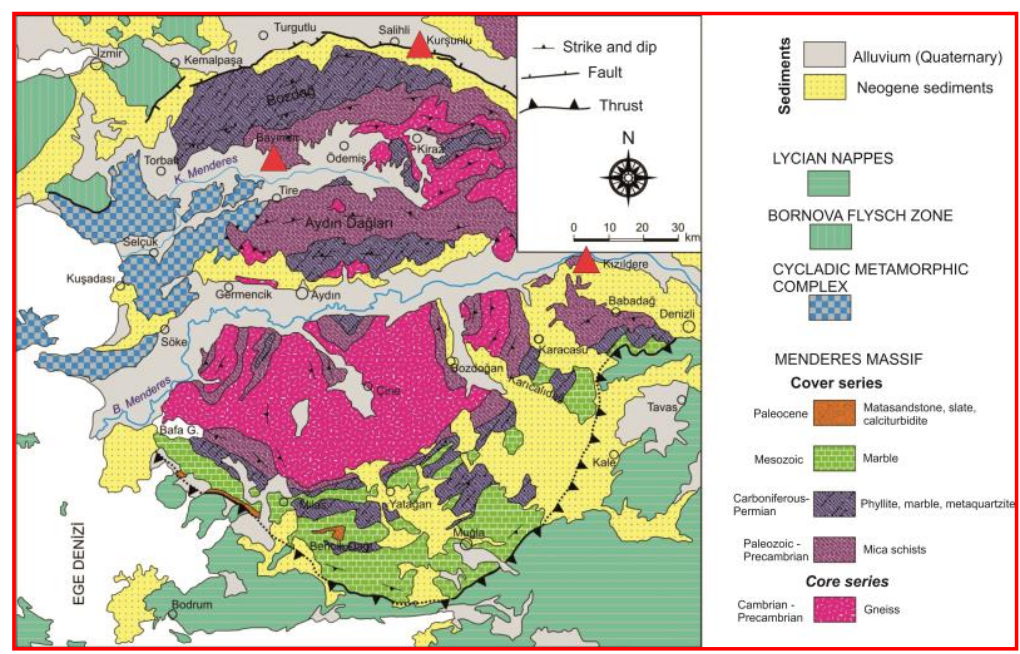

Figure 1 - Geological map of the of the Menderes Massif and continental rift zones with investigated active geothermal systems (modified from Okay, 2001).

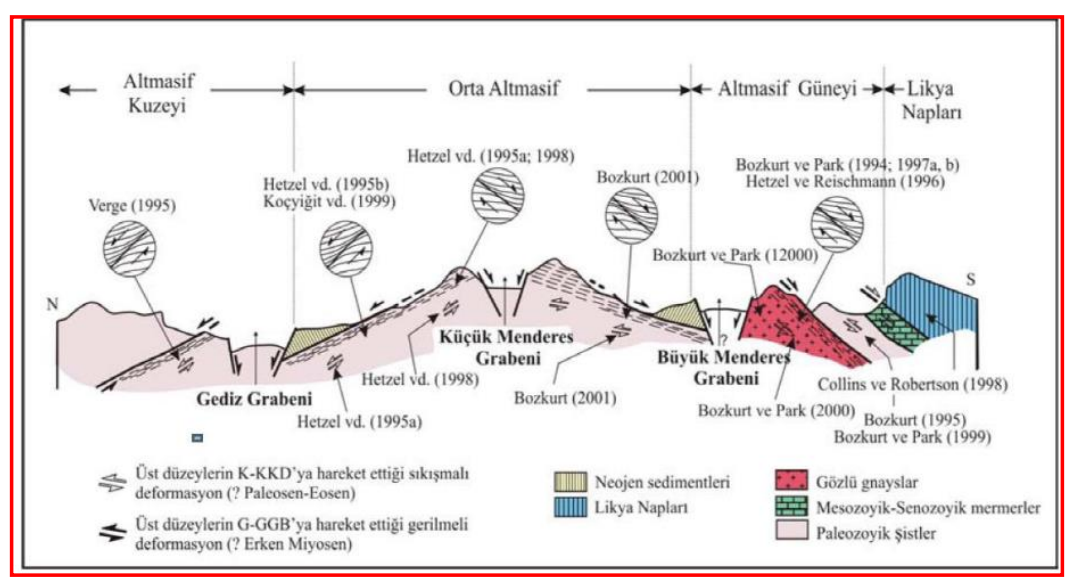

Figure 2. N-S schematic cross section through the Menderes Massif (Bozkurt, 2001).

\section{Geologic setting}

The present-day geothermal waters of Kızıldere, Bayındır and Kurşunlu are located in the rift zones of the Büyük Menderes, the Küçük Menderes and the Gediz within the Menderes Massif (Figure 1 and 2). The Menderes Massif is one of the oldest basements in Turkey and consists of (i) gneiss-core surrounded by a schist and marble envelope and (ii) an intensely deformed volcano-sedimentary sequence with incipient HP/LT metamorphism (Dora et al., 1995). The rift zones with present-day geothermal waters are the results of an extension which is believed to be closely related to the 
northward movement of the Arabian plate in the east pushing Anatolia westwards through the North Anatolian and East Anatolian Faults. The southerly bending of the North Anatolian Fault in the northern Aegean and Greece prevents the escape of the Anatolian plate further westwards placing the system in a locking geometry (Dewey and Şengör, 1979). This creates an E-W compression in the Menderes Massif which is relieved by N-S extension. The driving force of extension in the Aegean is believed to be subduction along Hellenic Trench (McKenzie, 1978).

Firstly, the geothermal field of Kizildere and environs consists of Paleozoic metamorphic rocks and Tertiary to Quaternary sediments (Şimşek, 1985; Özgür, 1998, 2003). The metamorphic rocks are of gneisses, mica schists and İğdecik formation composed of mica schists, quartzites and marbles. The gneisses are located in NW part of the investigated area and show an immediately change with high metamorphic mica schists. The tourmaline contents in gneisses are remarkable which plays together with biotites an important role for high boron contents in geothermal waters. The mica schists overlie the gneisses and are considered as garnet-muskovite-biotite-schist. The İğdecik formation, which forms the last upper sequence in the geothermal field of Kizıldere, consists of an alternation of mica schists, quartzites and marbles and shows light metamorphic features. It is traversed by ruptures and fissures and forms the second reservoir with a temperature of $216^{\circ} \mathrm{C}$ (Şimşek, 1985). The Pliocene sediments are of continental lacustrine and overlie metamorphic basement. The sedimentation inserted in Late Miocene and continues up today. These sediments can be divided stratigraphically as follows:

(1) The Kizılburun formation consists of basic conglomerates, which are made up of good rounded gravels of metamorphic origin, clay stones, fine-graded sandstones and marls. This indicates a total thickness of about $300 \mathrm{~m}$ and forms in the field a morphological monad lock due to high degree of consolidation. Because of the high clay contents, the Kizilburun formation forms a ceiling of an aquiferous layer. The Kizilburun formation can be considered as good rocks for the formation of geothermal waters due to high contents of clay minerals.

(2) The Sazak formation stands particularly in contrast to other sediment formations due to its distinctly high carbonate contents. It consists of limestones predominantly which is more clayey and sandy in dependence upon facies. Moreover, a little amount of marls and sandstones can be compared additionally. The total thickness of the Sazak formation is varying between 150 and 400 $\mathrm{m}$. Tectonically, this formation is the hardest in geothermal field due to hydrothermal alteration of silification and reacts brittle and jointed outermost. This is a reason for the accumulation of block debris in valleys in which the tectonical and physical erosion is faster than the chemical. The Sazak formation is strong fractured, porous to pitted and thereby an excellent reservoir. Therefore, it forms the first reservoir in the field of Kizıldere with a temperature of $198^{\circ} \mathrm{C}$. Due to its particular features, the Sazak formation as a reservoir of geothermal waters has been located in the center of the continental rift zone (Guidi et al., 1990; Özgür, 2010). Sözbilir (1995) indicates an age of Late Miocene to Pliocene for the Sazak formation.

(3) The Kolonkaya formation consists of marl, siltstone, sand with gravels and weak cemented sands which displays the features of typical fan delta. There are a great number of sedimentary soft deformation structures in medium grained, weak cemented sands, silts and marls especially. In this formation, load prints, drop structures, fire structures, debris intrusions, disrupted layer, slump structures and synsedimentary faults can be observed. This has a thickness of $500 \mathrm{~m}$ and is distinguished by a local hydrothermal alteration of silification \pm hematitization at the outlets of geothermal waters and steams.

(4) As a youngest, Pliocene to Plio-Quaternary sediment formation, the Tosunlar formation in the geothermal field of Kizildere shows an insignificant degree of consolidation, differs from the Kolonkaya formation scarcely and forms an alternation of sandstones, gravel stones, fine-graded sandy and clayey marls and limestones. It changes into Quaternary alluvium and is cultivated partly. This has a thickness of $500 \mathrm{~m}$. 
The Pliocene sedimentary rocks in the geothermal field of Kizıldere show already from distance intense colored zones. Near the surface, the marls and limestones of the Kolonkaya and Tosunlar formations vary from pale white to yellow, orange and brown to dark red colored shapes. Responsible for the colors are iron mineralizations, but the fading is a result of the phenomena of carbonatization (Özgür et al., 1998b). In this process, the carbonic acid in geothermal waters determines whether these waters will dissolve carbonates (limestones and marls) or precipitate them as follows:

$$
\text { erosion }
$$

$\mathrm{CaCO}_{3}+\mathrm{H}_{2} \mathrm{CO}_{3} \quad \Leftrightarrow \quad \mathrm{Ca}^{2+}+2 \mathrm{HCO}_{3}$

Solid solution deposition solution solution

In contrast to other type of hydrothermal alteration, it is a formation of carbonate paragenesis by introduction of $\mathrm{CO}_{3}{ }^{2-}$ which is able to fix metal ions such as $\mathrm{Mg}^{2+}, \mathrm{Fe}^{3+}, \mathrm{Ca}^{2+}$, and $\mathrm{Mn}^{2+}$. Therefore, many different kinds of carbonatization can be discriminated. Dolomitization of limestones by magnesium metasomatism is a simple base-exchange process and one of them. Two and more different types of carbonates can occur in the same alteration zone depending upon the chemical composition of the rocks and the solutions. In Kizıldere, the carbonates of Kolonkaya formation are dissolved at one place and precipitated at another by hydrothermal solutions which can be explained by the changes of physicochemical parameters of hydrothermal fluids.

(5) In Middle Miocene, the continental rift zone of the Büyük Menderes forms, which shows a E-W trending general strike. Tectonically, the geothermal waters in Kizldere and environs are associated with the faults in NW-SE or NE-SW directions which are located diagonal to general strike. These subsequent faults can be generated by a compression situation, which leads to a deformation of two horst areas lying between two extension rifts. The rift zone of the Büyük Menderes is associated with geothermal waters in Kızıldere and other localities and volcanic rocks in Denizli, Söke und Selçuk. The volcanic rocks in Denizli show an Upper Pliocene age, during the volcanic rocks of Kula in the rift zone of the Gediz have an age varying from 7,5 Ma to 18.000a (Ercan et al., 1992).

Within the Menderes Massif, the geothermal field of Bayındır is located in the northern part of the rift zone des Küçük Menderes and in southwestern part of Permokarboniferous and autochthonous alternation of phyllite, muscovite-quartz-schist and marble (Özgür, 1998). It stretches from Bayındır in the rift zone of the Küçük Menderes to Salihli in the rift zone of the Gediz overthrusted on the autochthonous schists as core rocks of the Menderes Massif, is considered as Bayındır formation (Dürr et al., 1995). This overthrust is distinguished by the 100 to km extending Bozdağ overthrust. The area is characterized by E-W trending rift faults and NE-SW or NE-SW trending younger faults. The one of these NE-SW trending faults is Ilica Dere fault, which corresponds with Ilica stream and is distinguished by the hot springs in Dereköy. In this village of Dereköy, the geothermal waters are produced by production wells and used for balneological purposes.

The Permokarboniferous metamorphic intercalation of mica schist, quartzite and marble forms the basement in the study area. Stratigraphically, the quartzites form the oldest rocks und are distinguished by an exemplary developed fracture system, which is very important for the formation of reservoir of geothermal waters. The thickness of this rock sequence is varying between 50 and $100 \mathrm{~m}$. The rock is composed from 60 to 70 percent of quartz, 23-35 percent of muscovite and 5 percent of opaque minerals. As accessory components, it contains feldspar, tourmaline, chlorite, calcite, rutile and zircon. The opaque components are graphite, hematite, pyrite and iron hydroxide. The mica schists show an alternation with quartzites and marbles and display a fine to $\mathrm{mm}$-sphere reaching schistosity. The mica schists are composed from 25-65 percent of muscovite, 20-30 percent of quartz, 15-20 percent of secondary constituents, zoisite and clinozoisite and tourmaline, feldspar, biotite, hematite and zircon as accessory minerals. The mica schists are impermeable and play an important role for the formation geothermal water reservoir in quartzites and marbles with good fracture system; thereby, mica schists can be considered as impermeable cap rocks as well as basement. The marbles occur in mica schists as an alternation and have a thickness from 10 to $200 \mathrm{~m}$. These rocks show a good developed fracture system which is of very good importance for the formation of reservoir of geothermal waters. The 
marbles are composed from 50-85 percent of calcite, 15-35 percent of quartz, muscovite and up to 10 percent of opaque components such as graphite, magnetite and limonite. As accessory minerals, chlorite, zoisite, zircon and pyrite occur in the rocks.

The geothermal fields of Kurşunlu and Çamurlu at Salihli in the rift zone of the Gediz are composed of Permokarboniferous metamorphic rocks, Miocene to Pliocene sedimentary rocks and Quaternary alluvium. The Precambrian to Cambrian gneisses are located in the southern part of the geothermal field, form the basement in the study area and overlined by mica schists. The mica schists show an alternation of phyllites, quartzites and marbles. Thereby, quartzites and marbles have good developed fracture system and can be, therefore, considered as reservoir rocks. These impermeable mica schists play a role of cap rocks and basement. The mica schists separate by a detachment fault from the Miocene to Pliocene sedimentary rocks (Hetzel, 1995; Özgür, 1998).

\section{Hydrogeological features}

In the study area of Kizildere, the groundwaters flow northwards at the northern side of the continental rift zone of the Büyük Menderes within the Buldan Horst, where the geothermal waters are supplied immediately (Figure 3). The distance from the watershed to the geothermal waters is about $10 \mathrm{~km}$. Consequently, the drainage area occupies an area from 100 to 150 square kilometer. With an annual precipitation of $430,15 \mathrm{~mm}$ and average annual temperature of $17,6^{\circ} \mathrm{C}$, the region of Kizıldere has semiarid climatic conditions. A great part of the precipitation takes place in the winter months from December to March, during aridity is predominant in the remainder of the time. The time of aridity leads to a deficit of groundwater; therefore, the surface waters play a secondary role for the feeding of geothermal waters only. In the study area, two geothermal power plants exist. The first one was installed 1984 with a capacity of $17.5 \mathrm{MWe}$. The second one has been installed in the beginning of 2000 with a capacity of 80 MWe. Up to 2018, the third one with a capacity of 100 MWe will be installed. The geothermal waste waters are reinjected into the reservoirs. The river of the Büyük Menderes is a watercourse which springs as karst spring at Dinar near Isparta, flows past by Sarayköy, Aydın and Söke and leads into Aegean Sea at Akköy. The discharge rate of river is $15-20 \mathrm{~m}^{3} / \mathrm{s}$ in winter and $2 \mathrm{~m}^{3} / \mathrm{s}$ in summer.

The geothermal waters of Kizildere show two different reservoirs, namely the first reservoir of Sazak formation in depth of about $400 \mathrm{~m}$ and the second reservoir of Igdecik formation in depth from 1000 to $2500 \mathrm{~m}$. Thereby, the second reservoir consists of Paleozoic schists, quartzites and marbles and forms the main reservoir for the explotation of geothermal waters in Kizlldere. The reservoir temperatures lie in the range from 148 to $198^{\circ} \mathrm{C}$ in the Sazak formation and in the range from 200 to $250^{\circ} \mathrm{C}$ in the İğdecik formation. According to Şimşek (1985), the gneisses in further depth form a third reservoir with temperatures from 250 to $260^{\circ} \mathrm{C}$. A lowering of the pressure of geothermal waters in the reservoir can be established due to extremely productions. Moreover, there are hits for the shift of points of steam outlets from higher areas to lower located areas today. This shows disappear of the old points of steam outlets. It shows, that a distinct lateral movement of the fields of steam outlets to catchment area of the geothermal power plant took place. The lowering of the steam outlet level of about 100 up to $150 \mathrm{~m}$ is a decrease of pressure of about 15 bar. The surface temperatures show 96$100^{\circ} \mathrm{C}$ in Kızıldere, $62-88^{\circ} \mathrm{C}$ in Tekkehamam and Babacık, $37-55^{\circ} \mathrm{C}$ in Pamukkale and Karahayıt and $40-54^{\circ} \mathrm{C}$ in Yenice I and II, during Na/K-thermometer (Fournier, 1979) give reservoir temperatures of $220-248^{\circ} \mathrm{C}$ in K1zıldere, $211-234^{\circ} \mathrm{C}$ inTekkehamam and Babacık, $260-313^{\circ} \mathrm{C}$ in Pamukkale and Karahayit and $251-288^{\circ} \mathrm{C}$ in Yenice I and II.

Groundwaters flow in the drainage area of geothermal field in Bayındır is southwards on the northern part of the rift zone of the Küçük Menderes in Bozdag Horst, where geothermal water reservoir is supplied by meteoric groundwaters; thereby, the Ilica creek plays an important role (Figure 4). The distance from the northern watershed is about $10 \mathrm{~km}$. The drainage area occupies an area of 50-100 square kilometers. With an average annual precipitation of $652 \mathrm{~mm}$ and an average annual temperature 
of $17,4^{\circ} \mathrm{C}$, the study area has a semiarid climatic conditions. A great part of precipitation is the result of months from December to March, during aridity of the time is predominant else. This aridity of the time leads to a groundwater deficit; therefore, the deep holes in the rift zone of the Küçük Menderes for irrigation applications. In summer time, the agricultural irrigation leads to shortage of groundwater additionally. The Küçük Menderes is watercourse which springs at Bozdağ near Kiraz, flows by Ödemiş and Bayındır and leads into Aegean Sea near Selçuk.

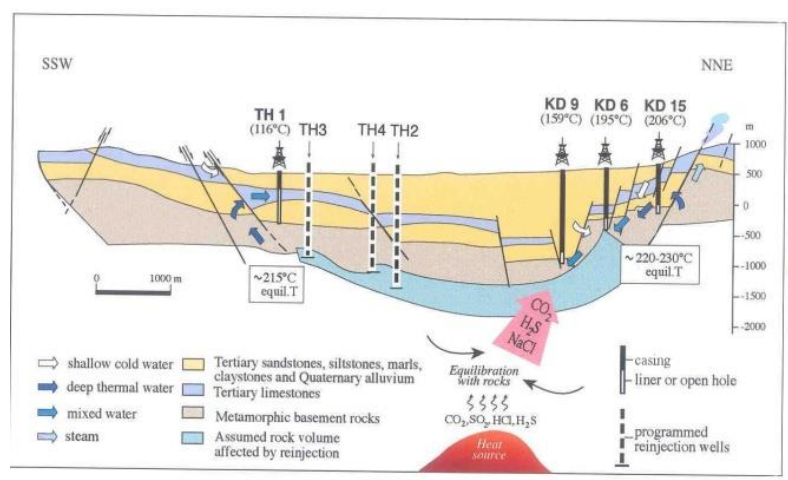

Figure 3 - Simplified model of the geothermal waters of Kizıldere in the rift zone of the Büyük Menderes within the Menderes Massif (Özgür, 1998).

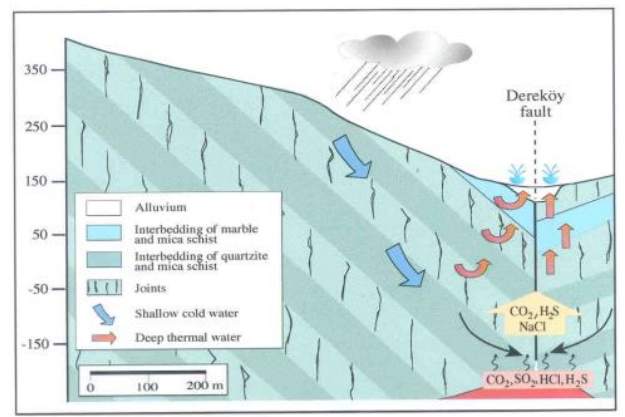

Figure 4 - Simplified model of the geothermal waters of Bayındır in the rift zone of the Küçük Menderes within the Menderes Massif (Özgür, 1998).

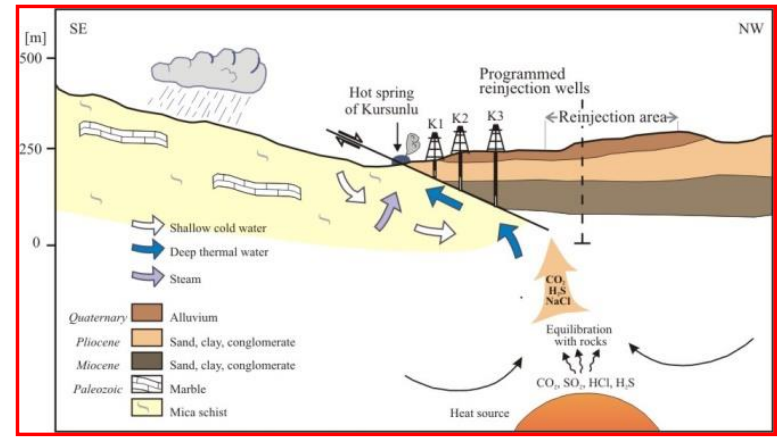

Figure 5 - Simplified model of the geothermal waters of Salihli in the rift zone of the Gediz within the Menderes Massif (Özgür, 1998).

In Salihli, groundwaters flow in the drainage area of the geothermal fields of Kurşunlu and Çamurlu is northwards on southern part of the rift zone of the Gediz; thereby, the geothermal water reservoir is supplied by groundwater dominantly in meteoric origin (Figure 5). The distance from the watershed in Bozdağ Horst to geothermal fields of Kurşunlu and Çamurlu is about $10 \mathrm{~km}$. The drainage area of the 
geothermal fields occupies a total area of about $150 \mathrm{~km}^{2}$. With an average annual precipitation of 652 $\mathrm{mm}$ and an average annual temperature of $16,6^{\circ} \mathrm{C}$, the drainage area of both geothermal fields have a semiarid climatic conditions. The Gediz is a watercourse which springs in the northern part of Kula, is supplied by a system of tributaries and leads into Aegean Sea in the northern part of İzmir. The discharge rate of the Gediz is at $20-25 \mathrm{~m}^{3} / \mathrm{s}$ in winter and $3-5 \mathrm{~m}^{3} / \mathrm{s}$ in summer.

\section{Hydrogeochemical features}

During the present study, the outflow of 20 geothermal springs, 12 drill holes, 16 groundwater springs were sampled in different seasons from 1992 up to now. Additionally, we have collected about two hundred rock samples (Özgür, 1998). Generally, the geothermal waters of Kızıldere, Bayındir and Salihli can be classified as $\mathrm{Na}-\left(\mathrm{SO}_{4}\right)-\mathrm{HCO}_{3}$ type (Fig. 6). In the drainage area of Kizıldere, the geothermal waters of Kizıldere, Tekkehamam and Babacık Pınarı can be classified as $\mathrm{Na}-\left(\mathrm{SO}_{4}\right)-\mathrm{HCO}_{3}$ type exchange waters, during the geothermal waters of Pamukkale and Karahayit show Ca-Mg- $\mathrm{HCO}_{3}$ type exchange waters (Özgür, 1998). The origin of $\mathrm{Na}^{+}$in the geothermal waters is linked to metamorphic rocks in substratum, while carbonate rocks in the reservoirs form the origin for $\mathrm{Ca}^{2+}$ and $\mathrm{Mg}^{2+}$.

The high-temperature geothermal waters of Kizıldere demonstrate TDS (total dissolved solids) values from 5000 to $5500 \mathrm{mg} / \mathrm{l}$ and high mineralization rate (Özgür, 1998). Before the separator, the $\mathrm{pH}$ values of these waters range from 6 to 7 , which correspond with the $\mathrm{pH}$ values of natural geothermal springs in the environs. The HS- ions in Babacık Pınarı show values up to $5 \mathrm{mg} / \mathrm{l}$. In comparison, the geothermal waters of Kizıldere show $\mathrm{HS}^{-}$values below $0,02 \mathrm{mg} / \mathrm{l}$. The magmatic sulfur promotes as a source for $\mathrm{H}_{2} \mathrm{~S}, \mathrm{H}_{2}$ and $\mathrm{SO}_{4}{ }^{2-}$ (Hattori and Cameron, 1986). The entry in sulfur compound can be assimilated and transported to the surface which could be observed in reinjection wells in Tekkehamam in depth of $2000 \mathrm{~m}$ and in Kizıldere in depth of $2261 \mathrm{~m}$ (Özgür, 1998, 2013). $\mathrm{HS}^{-}$or $\mathrm{H}_{2} \mathrm{~S}$ ions in geothermal waters, which are either magmatic origin or can be dissolved from sulfides by weathering, can be oxidized and ascend to the surface and set sulfur free (Özgür, 1998, 2013). In the carbonate-bearing sediments, which are associated with geothermal springs immediately, gypsum efflorescences could be observed. The formation of gypsum stand in contrast to carbonatization thereby (Özgür et al., 2004). It indicates thereby, that the sulfur system carrys the principal responsibility; thereby, the existence of water is assumed.

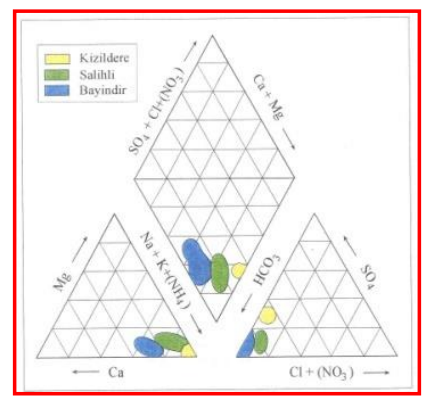

Figure 6 - Geothermal waters of the geothermal fields of Kızıldere, Bayındır and Salihli within the Menderes Massif (Özgür, 1998).

Hydrogeochemically, the geothermal waters of Kizıldere and environs are distinguished by (i) an enrichment of $\mathrm{F}^{-}, \mathrm{Si}^{4+}$ and $\mathrm{B}^{3+}$, (ii) an enhancement of trace metals such as $\mathrm{As}^{3+}$ and $\mathrm{Sb}^{3+}$ and (iii) a depletion of base metals in combination with $\mathrm{Fe}^{2+}$ and $\mathrm{Mn}^{2+}$ (Özgür, 1998). $\mathrm{B}^{3+}$ occurs in the geothermal waters with values of up to $30 \mathrm{mg} / \mathrm{l}$ (Özgür, 1998, 2001). The origin of enriched $\mathrm{B}^{3+} \mathrm{can}$ be linked to the solubility product by fluid-rock interaction in the reservoir; thereby, the magmatic origin can not be ruled out completely. 
According to the tendency, the volatile components of $\mathrm{CO}_{2}, \mathrm{HS}^{-}$and $\mathrm{NH}_{3}$ indicate a magmatic input; this could be confirmed by isotope analyses of ${ }^{11} \mathrm{~B} /{ }^{10} \mathrm{~B}$ conditionally. In connection with fluid-rock interaction, the boron contents in geothermal waters can be leached from mineral phases such as tourmaline and biotite in metamorphic rocks and boron minerals in sedimentary rocks. The experimental leaching tests of different rocks from Kizıldere show, that gneiss and mica schist play an important role as boron source. The geothermal waters in Kizıldere and environs represent fluorine contents up to $35 \mathrm{mg} / \mathrm{l}$ (Özgür, 1998). On the one hand, these high contents can be led to a magmatic origin as volatile component; on the other hand, the increasing value of fluorine in geothermal waters depends upon $\mathrm{Ca}^{2+}$ contents, because there must be a corresponding $\mathrm{Ca}^{2+}$ offer in the environment in order to precipitate a corresponding amount of $\mathrm{F}^{-}$. Otherwise, fluorine ions remain released, and the fluid is enriched with $\mathrm{F}^{-}$. In depending upon temperature, fluorine and boron show a close correlation in geothermal waters of Kizıldere and environs (Özgür, 1995). Accordingly, fluorine and boron show an approximating positive correlation which is probably based on (i) interconnection of thermodynamic control process, (ii) applicability of boron as tracer and (ii) substitution of both elements in boron-bearing minerals.

The geothermal waters of K1zıldere represent average $\mathrm{Si}^{4+}$ contents of $115 \mathrm{mg} / \mathrm{l}$ (Özgür, 1998) which have been leached from the silicates in reservoir at a temperature of about $200{ }^{\circ} \mathrm{C}$ by fluid-rock interactions conditionally. Solubility equilibrium of Si depends upon the modification of amorphous silica, which allow high concentrations. The separation, where the geothermal waters are separated as steam and fluid phase, gives rises to a 25 percent water loss in terms of water steam, a $\mathrm{CO}_{2}$ leakage and a Si enrichment in the fluid on $150 \mathrm{mg} / \mathrm{l}$. Thereby, the $\mathrm{CO}_{2}$ leakage causes a $\mathrm{pH}$ increasing on 9 at a temperature of $100^{\circ} \mathrm{C}$. At a temperature of $45^{\circ} \mathrm{C}$, the geothermal waters in drainage basins represent average $\mathrm{Si}$ contents of $150 \mathrm{mg} / \mathrm{l}$ and a $\mathrm{pH}$ value of 9 . The geothermal waste waters of geothermal power plant of Kizildere should be reinjected, in order to supply the geothermal water reservoir constantly and remove agricultural danger for citrus fruits in the rift zone des Büyük Menderes in view of environmental aspects. The precipitation of $\mathrm{Si}$ as precipitates represents a danger potential for the reinjection system as documented by thermodynamic and kinetic results (Giese, 1997). Thereby, the Si precipitates occur in the reinjection well in depending upon time with regard to ion strength of $\mathrm{pH}$ values and temperature (below $100^{\circ} \mathrm{C}$ ).

The geothermal waters in Kizildere represent As values up to $1,08 \mathrm{mg} / \mathrm{l}$ and $\mathrm{Sb}$ values up to 0,21 $\mathrm{mg} / \mathrm{l}$ (Özgür, 1998). Die both elements of As and Sb in geothermal waters show a close correlation in depending upon temperature which is case in the rocks as well. The rocks of the geothermal field of Kizildere have Au contents up to 6 ppb and Sb contents ranging from 194 ppb to 1373 ppb. The cap rocks which are close connected with geothermal water reservoirs represent high Ag contents of 1,21 ppm; thereby, these high Ag contents in the metamorphic rocks are represented by a high background value of $0,5 \mathrm{ppm}$. It shows, that the metamorphic rocks form a formerly source for $\mathrm{Au}$ and $\mathrm{Ag}$. The carbonate and silicate precipitates show Au contents up to 3,5 ppm and Ag contents up to $194 \mathrm{ppb}$. The base metals in the geothermal waters show distinct low contents as expected.

The geothermal waters of Bayındir are distinguished by a temperature of $46^{\circ} \mathrm{C}$, a $\mathrm{pH}$ value of 6,9 , an Eh value of $-94 \mathrm{mV}$, an average EC value of $1015 \mu \mathrm{S} / \mathrm{cm}$ and an average TDS value of $1399 \mathrm{mg} / \mathrm{l}$ (Özgür, 1998, 2001, 2002) and differ from the surface waters and groundwaters in respect with hydrogeochemical composition and standardization distinctly. In comparison to Kiz1ldere, the geothermal waters of Bayındır show relative poor fluid-rock interaction in low- temperature spheres, how is generated a light paragenesis of alteration minerals.

In the geothermal fields of Salihli, there are five geothermal springs of Kurşunlu and Çamurlu and eight production wells (Özgür, 1998). Four of the geothermal springs are located in Kurşunlu with temperatures from 96 to $36^{\circ} \mathrm{C}$. One of them is situated in Çamurlu. The first well located near the geothermal spring has a depth of $42,5 \mathrm{~m}$, a surface temperature of $96^{\circ} \mathrm{C}$, a surface pressure of 5,5 to 6,0 bar and a flow rate of $20 \mathrm{l} / \mathrm{s}$. The second well is located in the northern part of the first well and represents a depth of $70 \mathrm{~m}$, a surface temperatures of $96^{\circ} \mathrm{C}$ and a flow rate of $45 \mathrm{l} / \mathrm{s}$. Thereby, the first 
$20 \mathrm{~m}$ depth consists of alluvium, the depth between 20,00 and $68,80 \mathrm{~m}$ is an alternation of mica schist and marble, and the depth between 68,80 and 70,00 $\mathrm{m}$ consists of marble. The third well is located in the northern part of the geothermal field of Kurşunlu and shows a depth of $117 \mathrm{~m}$, a surface temperature of $96^{\circ} \mathrm{C}$, a surface pressure of 5,5 to 6,0 bar and a flow rate of $80 \mathrm{l} / \mathrm{s}$. Drill $\log$ of this third well comprises Quaternary alluvium between 0 and $5 \mathrm{~m}$, Pliocene Sedimentary rocks in a thickness from 5 to $83 \mathrm{~m}$, Miocene conglomerate in depth from 83 to $92 \mathrm{~m}$, Paleozoic marble in depth from 92 to 104 $\mathrm{m}$ and Paleozoic alternation of mica schist and marble in depth from 104 to $117 \mathrm{~m}$.

In the geothermal field of Salihli, the geothermal waters differ from the groundwaters and surface waters hydrogeochemically (Özgür, 1998). The geothermal waters of Salihli are of Na-K-HCO ${ }_{3}$ type exchange water during the groundwaters show $\mathrm{Ca}-\mathrm{HCO}_{3}$ type. In comparison to Kizildere, the low contents of $\mathrm{F}^{-}, \mathrm{SO}_{4}{ }^{2-}, \mathrm{As}^{3+}$ and $\mathrm{Sb}^{3+}$ and the high contents $\mathrm{Mg}^{2+}$ and $\mathrm{Ca}^{2+}$ in geothermal waters of Salihli are conspicuous distinctly. The low contents of $\mathrm{F}^{-}$can be indicated with the increasing $\mathrm{Ca}^{2+}$ offer, because the both elements in fluids can be precipitated as $\mathrm{CaF}_{2}$. The ${ }^{3} \mathrm{H}$ isotopes in geothermal waters of Salihli show the existence of mixing water; therefore, the components of anions and cations are diluted in comparison to Kizıldere and occur in present concentrations.

The geochemical thermometer show reservoir temperatures of $147-170^{\circ} \mathrm{C}$ (quartz), $140160^{\circ} \mathrm{C}$ (quartz with steam loss), $120-145^{\circ} \mathrm{C}$ (chalcedony), $205-220^{\circ} \mathrm{C}(\mathrm{Na}-\mathrm{K}), 195-215^{\circ} \mathrm{C}(\mathrm{Na}-\mathrm{K}-\mathrm{Ca}), 35-135^{\circ} \mathrm{C}(\mathrm{Na}-$ $\mathrm{K}-\mathrm{Ca}-\mathrm{Mg}), \quad 240-260^{\circ} \mathrm{C}$ (Na-Li), $120-155^{\circ} \mathrm{C}(\mathrm{Mg}-\mathrm{Li})$ and $100-120^{\circ} \mathrm{C}(\mathrm{K}-\mathrm{Mg})$, thereby, the thermometers of Na-K, Na-K-Ca and quartz correspond with Özgür (1998) and are more suitable.

In order re-examine the calculated reservoir temperatures, an enthalpy versus $\mathrm{SiO}_{2}$ mixing model was used with respect to Fournier (1977; Figure 7). In the process, the used enthalpy values reflect surface temperatures and have been gathered from Henley et al. (1984). In this diagram, the mixing line cuts through quartz solubility curve which connects samples with meteoric groundwaters and geothermal waters at an enthalpy value at $880 \mathrm{kj} / \mathrm{kg}$ indicating a reservoir temperature of $205^{\circ} \mathrm{C}$. This temperature estimation is based on the assumption that the steam originated by the boiling was not separated from the residual liquid phase before mixing with cold groundwaters. When the steam loss takes place before the mixing with the cold groundwaters, the enthalpy accepts the value of waters at temperatures of steam phase of $96^{\circ} \mathrm{C}$; in this process, the initial enthalpy value lies at 620 $\mathrm{J} / \mathrm{g}$ which corresponds to a reservoir temperature of $148^{\circ} \mathrm{C}$.

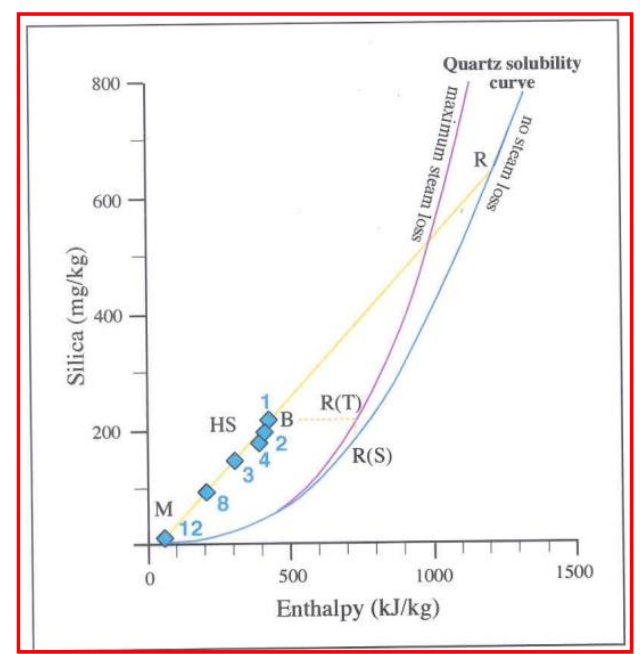

Figure 7 - Silica versus enthalpy mixing model of geothermal waters from Kurşunlu and Çamurlu in Salihli. 


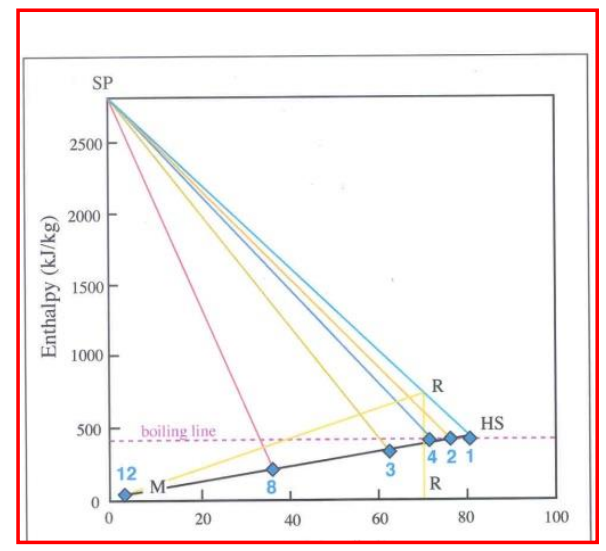

Figure 8 - Cl- versus enthalpy mixing model of geothermal waters from Kurşunlu and Çamurlu in Salihli.

A reliable calculation of temperature of geothermal water reservoir of Kurşunlu can be realized by using enthalpy versus Cl- mixing model according to Truesdell and Fournier (1975; Figure 8). In this process. the boiling point of geothermal waters is connected with a temperature of $97^{\circ} \mathrm{C}$ and $\mathrm{Cl}$ - contents of 72,2 $\mathrm{mg} / \mathrm{l}$. In this diagram, the boiling point of geothermal waters has an enthalpy value of $2670 \mathrm{kj} / \mathrm{kg}$ and an $\mathrm{Cl}$ - contents of $0 \mathrm{ppm}$. Firstly, the groundwater sample with geothermal water samples from Kurşunlu was drawn in the diagram. These are $\mathrm{Cl}$ - contents and measured surface temperatures. There, the mixing line affects boiling line at an enthalpy value of $500 \mathrm{kj} / \mathrm{kg}$ which corresponds a reservoir temperature of $120^{\circ} \mathrm{C}$. Finally, this leads to the reservoir temperatures of 148 to $205^{\circ} \mathrm{C}$, which corresponds to the calculated temperatures of quartz, Na-K, Na-K-Ca. The modeling indicates a $\mathrm{pH}$ values from 5,0 to 5,5 of the reservoirs of the geothermal waters in Kurşunlu and Çamurlu.

By using indicator matters, such as $\mathrm{Cl}-, \mathrm{B}, \mathrm{Li}$, and temperature, mixing ratio of geothermal waters and groundwaters can be calculated relatively. At Çamurlu, there is a moderate mixing ratio of 42,5 percent geothermal waters and 57,5 percent groundwaters. In comparison, 83,0 percent geothermal waters are connected with 17,0 percent groundwaters in Kurşunlu.

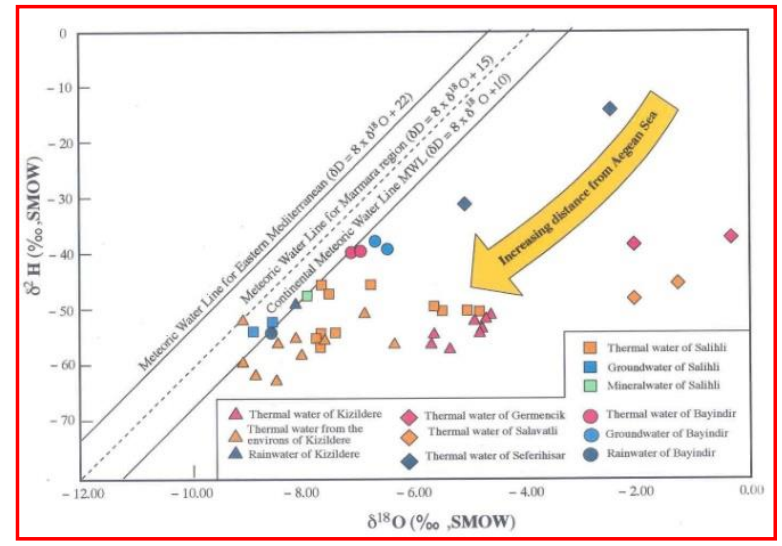

Figure 9 - Plot of $\delta^{2} \mathrm{H}$ versus $\delta^{18} \mathrm{O}$ of geothermal waters of Kızıldere, Bayındır and Salihli (Özgür, 1998). 


\section{Isotopic signatures}

The geothermal waters of Kizıldere, Bayındır and Salihli can be considered meteoric water due to isotope ratio of $\delta^{18} \mathrm{O}$ and $\delta^{2} \mathrm{H}$ (Figure 9). The ${ }^{3} \mathrm{H}$ contents in investigated geothermal waters are attributed to atmospheric and anthropogenic effects. They indicate, that the geothermal waters of Bayındır and Salihli can be considered as mixing water. The geothermal waters of Kizildere show scarcely mixing of young groundwaters, because ${ }^{3} \mathrm{H}$ contents are below the detection limit. The ratios of $\delta^{13} \mathrm{C}$ in groundwaters, mixing waters and geothermal waters reveal, that the origin of $\mathrm{CO}_{2}$ can be linked to a magmatic activity by a subvolcanism in basement and to reactions with carbonate rocks. The $\delta^{3} \mathrm{He}$ surplus in geothermal waters of Kizldere reveal interactions of these fluids with basic to intermediate still cooling volcanic rocks of mantel and the existence of a subvolcanic intrusion (Özgür, 1998). The $\mathrm{CO}_{2}$ production in connection with carbonate rocks in reservoir dilutes ${ }^{14} \mathrm{C}$ in geothermal waters, by which the age determination with ${ }^{14} \mathrm{C}$ is impossible almost.

\section{Discussion: hydrogeological modeling of the geothermal waters}

In the geothermal fields of Kızıldere in the rift zone of the Büyük Menderes, Bayındır in the rift zone of the Küçük Menderes, and Salihli with areas of Kurşunlu and Çamurlu in the rift zone of the Gediz, there are excellent conditions for the formation of geothermal waters. Firstly, the Paleozoic marbles and quartzites and Miocene limestones in Kizıldere, the Carboniferous to Permian marbles and quartzites in Bayındır, and the Paleozoic marbles and quartzites in Salihli play an important role for the formation of geothermal reservoirs. Secondly, the Pliocene Kizilburun formation, Kolonkaya formation and Tosunlar formation in Kızıldere and the Paleozoic mica schsits in Bayındır and Salihli can be considered as impermeable basement and cap rocks for the formation of geothermal reservoirs. Thirdly, the study areas of Kizıldere, Bayındır, and Salihli are of very active from the views of tectonical points. By the plate tectonical development, the Menderes Massif showed a dome shaped structure due to compressional tectonic features from Oligocene to Middle Miocene. From Early to Middle Miocene, the continental rift zones of the Büyük Menderes, the Küçük Menderes and the Gediz were formed by extensional tectonic features, which strike E-W generally and are represented by a great number of geothermal waters, epithermal mineralizations of $\mathrm{Hg}$, $\mathrm{Sb}$, and $\mathrm{Au}$, and volcanic rocks of Middle Miocene to recent. The geothermal waters are related to faults which strike preferentially NW-SE and NE-SW and locate diagonal to general strike of the rift zones.

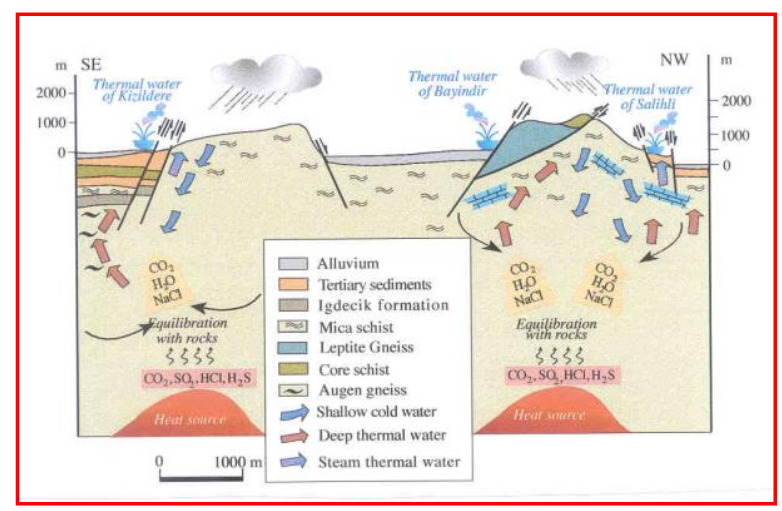

Figure 10 - Simplified presentation of geothermal model of the geothermal waters in the rift zones of the Büyük Menderes, Küçük Menderes and Gediz within the Menderes Massif (Özgür, 1998).

These faults are probably generated by compressional tectonic stress, which leads to the deformation of uplift between two extensional rift zones. This can be corroborated by the intensively earthquake activities in the study area. Lastly, some intrusive in the continental rift zones of the Menderes Massif, calcalkaline and basic to intermediate rocks exist which are generated from Middle Miocene 
to recent. The volcanic rocks are of products of continental crust based on isotope analyses of ${ }^{87} \mathrm{Sr} /{ }^{86} \mathrm{Sr}$ and ${ }^{144} \mathrm{Nd} /{ }^{143} \mathrm{Nd}$ and can be considered as heat source for the heating of geothermal waters in the rift zones and elsewhere.

In active geothermal fields of Kızıldere, Bayındır and Salihli, groundwater flow takes place in drainage areas from higher spheres around the watershed in horst to the lower located continental rift zones where the groundwaters find the watercourse ultimately (Figure 10).

These meteoric waters in the drainage area percolate at fault zones and permeable clastic sediments into the reaction zone of the roof area of a magma chamber situated in a probable depth of up to 5 $\mathrm{km}$ where meteoric fluids are heated by the cooling magmatic melt and ascend to the surface due to their lower density caused by convection cells. The volatile components of $\mathrm{CO}_{2}, \mathrm{SO}_{2}, \mathrm{HCl}, \mathrm{H}_{2} \mathrm{~S}$, $\mathrm{HB}, \mathrm{HF}$, and $\mathrm{He}$ out of the magma reach the geothermal water reservoir where an equilibrium between altered rocks, gas components, and fluids performs. Thus, the geothermal waters ascend in the tectonical zones of weakness at the continental rift zones of the Menderes Massif in terms of hot springs, gases, and steams. These fluids are characterized by high to medium $\mathrm{CO}_{2}, \mathrm{H}_{2} \mathrm{~S}$ and $\mathrm{NaCl}$ contents. It is very important, that the fluids indicate a reduced $\mathrm{pH}$-neutral environment after equilibrium adjustment with hard rocks in the reaction zone, namely in the roof area of magma chamber (Giggenbach, 1992). In superficial areas, i.e. beneath a depth of $550 \mathrm{~m}$ in Kizıldere with a pressure of 50 to $100 \mathrm{bar}$, a temperature of 200 to $220^{\circ} \mathrm{C}$ and a $\mathrm{pH}$ value of lesser than 5,0, it comes to boiling by decrease of pressure; thereby, $\mathrm{CO}_{2}$ and $\mathrm{H}_{2} \mathrm{~S}$ rich steams are splitted off from geothermal waters which can lead to formation of sulfate rich waters after condensation and surface oxidation. The geothermal waters are exploited for various uses consequently, i.e. for geothermal energy, balneology, and green houses.

\section{Acknowledgments}

This work has been supported by the Commission for Research and Scientific Training for New Recruits, Freie Universität Berlin.

\section{References}

Bozkurt, E. and Park, R.G., 1994. Southern Menderes Massif: an incipient metamorphic core complex in western Anatolia, Turkey, J. Geol. Soc. Lond., 151, 213-216.

Bozkurt, E., 1995. Deformation during main Menderes metamorphism (MMM) and its tectonic significance: evidence from southern Menderes Massif, western Turkey, Terra, 7, 176.

Bozkurt, E. and Park, R.G., 1997. Evolution of mid-Tertiary extensional shear zone in the southern Menderes Massif, western Turkey, Soc. Geo. Fr. Bull., 168, 3-14.

Bozkurt, E. and Park, R.G., 1997. Microstructures of deformed grains in the augen gneisses of southern Menderes Massif and their tectonic significance, Geol. Rundsch., 86, 103-119.

Bozkurt, E. and Park, R.G., 1999. The structure of the Paleozoic schists in the southern Menderes Massif, western Turkey: a new approach to the origin of the main Menderes metamorphism and its relation to the Lycian Nappes, Geodinamica acta (Paris), 12, 25-42.

Bozkurt, E., 2001. Late Alpine evolution of the central Menderes Massif, Western Turkey, Internat. J. Earth Sci., 89, 728-744.

Collins, A.S. and Robertson, A.H.F., 1998. Processes of Late Cretaceous to Late Miocene episodic thrust-sheet translation in the Lycian Taurides, SW Turkey, J. Geol. Soc. Lond., 155, 759-772.

Dewey, J.F. and Şengör, A.M.C., 1979. Aegean and surrounding regions: complex multiplate and continuum tectonics in a convergent zone, Geol. Soc. Am. Bull., Part I, 90, 84-92.

Dora, O.Ö., Candan, O., Dürr, S. and Oberhänsli, R., 1995. New evidence on the geotectonic evolution of the Menderes Massif. In: Pişkin, Ö., Ergün, M., Savaşçın, M.Y. and Tarcan, G., eds., Proc. Internat. Earth Sci. Colloquium on Aegean Region, 9-14 October 1995, İzmirGüllük, Turkey, 1, 53-72. 
Dürr, S., Dora, O.Ö., Candan, O., Özer, S. and Güngör, T., 1995. Stratigraphy and tectonics of the Menderes Massif, Proc. Internat. Earth Sci. Congr. on Aegean Regions, İzmir/Güllük/Turkey, Excursion Guide, $10 \mathrm{pp}$.

Ercan, T., Dinçel, A., Türkecan, A. and Erdoğdu, G., 1992. Petrochemical characteristics and genetic interpretation of the basaltic volcanism of Kula (Manisa, Turkey), Geologica Balcanica, 22, 51-73.

Fournier, R.O., 1997. Chemical geothermometers and mixing models for geothermal systems, Geothermics, 5, 41-50.

Fournier, R.O., 1979. A revised equation for the Na/K geothermometer, Geoth. Res. Council. Trans., 3, 221-224.

Giese, L., 1997. Geotechnische und umweltgeologische Aspekte bei der Bohrung und Reinjektion von Thermalfluiden zur Nutzung geothermischer Energie am Beispiel des Geothermalfeldes Kızıldere und des Umfeldes, W-Anatolien, Türkei, Ph.D. thesis, Freie Universität Berlin, $201 \mathrm{pp}$.

Giggenbach, W.F., 1992. Magma degassing and mineral deposition in hydrothermal systems along convergent plate boundaries, Econ. Geol., 87, 1927-1944.

Guidi, M., Marini, L. and Principe, C., 1991. Hydrogeochemistry of K1z1ldere geothermal system and nearby region, Geothermal Resources Council Transactions, 14, 901-908.

Hattori, K. and Cameron, E.M., 1986. Archaean magmatic sulphate, Nature, 319/60842, 45-47.

Hetzel, R., 1995. The Alpine tectono-metamorphic evolution of the Menderes Massif, southwerstern Turkey, Ph. D. thesis, Johannes Gutenberg Universität Mainz, 79 pp.

Hetzel, R., Passchier, C.W., Ring, U. and Dora, O.Ö., 1995a, Bivergent extension in orogenic belts: the Menderes Massif (southwestern Turkey), Geology, 23, 455-458.

Hetzel, R., Ring, U., Akal, C. and Troesch, M., 1995. Miocene NNE-directed extensional unroofing in the Menderes Massif, southwestern Turkey, J. Geol. Soc., London, 152, 1-16.

Hetzel, R., Romer, R.L., Candan, O. and Passchier, C.W., 1998. Geology of the Bozdağ area, central Menderes Massif, SW Turkey: Pan-African basement and Alpine deformation, Geol. Rundsch., 87, 394-406.

Hetzel, R. and Reischmann, T., 1996. Intrusion age of Pan-African augen gneisses in the southern Menderes Massif and the age of cooling after after Alpine ductile extensional deformation. Geol. Mag., 133, 565-572.

Koçyiğit, A., Yusufoğlu, H. and ve Bozkurt, E., 1999. Evidence from the Gediz graben for episodic two-stage extension in western Turkey, J. Geol. Soc. Lond., 156, 605-616.

McKenzie, D.P., 1978. Active tectonics of the Alpine-Himalayan belt: the Aegean and the surrounding regions, Geophys. J. R. Astr. Soc., 55, 217-254.

Okay, A., 2001. Stratigraphic and metamorphic inversions in the Central Menderes Massif: A new structural model, J. Earth Sciences, 89, 709-727.

Özgür, N., Halbach, P., Pekdeğer, A., Sommer-von Jarmersted, C., Sönmez, N., Dora, O.Ö., Ma, D.-S., Wolf, M. and Stichler, W., 1997. Epithermal antimony, mercury, and gold deposits in the rift zone of the Küçük Menderes, Western Anatolia, Turkey: preliminary studies. In: Papunen, H., ed., Mineral Deposits, Research and Exploration (Where do they meet ?), Proc. $4^{\text {th }}$ Biennial SGA Meeting, Turku, Finland, August, 11-13, 269-272.

Özgür, N., 1998. Aktive und fossile Geothermalsysteme in den kontinentalen Riftzones des Menderes Massives, W-Anatolien, Türkei, Habilitationsschrift, Freie Universität Berlin, 171 pp.

Özgür, N., Pekdeğer, A., Wolf, M., Stichler, W., Seiler, K.P. and Satır, M., 1998. Hydrogeochemical and isotope geochemical features of the thermal waters of Kizıldere, Salavatli, and Germencik in the rift zone of the Büyük Menderes, western Anatolia, Turkey: Preliminary studies. In: Arehart, G.B. and Hulston, J.R., eds., Proc. Internat. 9th Symp. on Water-Rock Interaction, Taupo, New Zealand, 30 March-3 April 1998, (1998a), 645-648.

Özgür, N., Vogel, M. and Pekdeğer, A., 1998. A new type of hydrothermal alteration of the K1zıldere geothermal field in the rift zone of the Büyük Menderes, western Anatolia, Turkey. In: Arehart, G.B. and Hulston, J.R., eds., Proc. Internat. 9th Symp. on Water-Rock Interaction, Taupo, New Zealand, 30 March-3 April 1998, (1998b), 679-682. 
Özgür, N., 2001. Origin of the high boron contents in the thermal waters of the rift zones of the Menderes Massif, Western Anatolia, Turkey, International Geology Review, 43, 910-920.

Özgür, N., 2002. Geochemical signature of the Kızıldere geothermal field, Western Anatolia, Turkey, International Geology Review, 44, 153-163.

Özgür, N., 2003. Aktive geothermal systems in the rift zone of the Büyük Menderes, western Anatolia, Turkey, www.geothermie.de/egec-geothernet/proceeedings/szeged/o-5-04.pdf, 28 August, 2003.

Özgür, N., Graf, W., Stichler, W. and Wolf, M., 2014. Origin of high sulfate contents in the thermal waters of Kizıldere and environs, western Anatolia, Turkey, In: Chatzipetros, A.A. and Pavlides, S.B., eds., Proc. 5th Internat. Symp. on Eastern Mediterranean Geology, Thessaloniki, Greece, 14-17 April 2014, 1306-1309.

Özgür, N., 2010. Hydrogeological, hydrogeochemical, and isotope geochemical modeling of the thermal waters of the Menderes Massif, western Anatolia, Turkey, Proc. World Gothermal Congress, 25-29 April 2010, Bali Indonesia.

Özgür, N., 2013. Hydrogeological, hydrogeochemical, and isotope geochemical modeling of the thermal waters of the Menderes Massif, western Anatolia, Turkey, Proc. 38th Workshop on Geothermal Reservoir Engineering, Stanford University, Stanford, California, February 2013, SGP-TR 198.

Simşek, Ș., 1985. Geothermal model of Denizli, Sarayköy-Buldan area, Geothermics, 14, 393-417.

Sözbilir, H., 1995. Stratigraphy and provenance of the Paleocene-Eocene Alakaya Basin in the Denizli Province, southwestern Turkey, In: Pişkin, Ö., Ergün, M., Savaşçın, M.Y. and Tarcan, G., eds., Proc. Internat. Earth Sci. Colloquium on Aegean Region, 9-14 October 1995, İzmir-Güllük, Turkey, 1, 309-329.

Verge, N.J., 1995. Oligo-Miocene extensional exhumation of the Menderes Massif, western Anatolia, Terra, 7, 117. 